University of Nebraska - Lincoln

DigitalCommons@University of Nebraska - Lincoln

USDA National Wildlife Research Center - Staff Publications
U.S. Department of Agriculture: Animal and Plant Health Inspection Service

2015

\title{
Anthraquinone-based repellent for horned larks, great-tailed grackles, American crows and the protection of California's specialty crops
}

\author{
Scott J. Werner \\ United States Department of Agriculture, Animal and Plant Health Inspection Service, Wildlife Services, \\ National Wildlife Research Center, Fort Collins, CO, scott.j.werner@aphis.usda.gov \\ Shelagh T. DeLiberto \\ USDA/APHIS/WS National Wildlife Research Center, shelagh.t.deliberto@usda.gov
}

Anna M. Mangan

United States Department of Agriculture, Animal and Plant Health Inspection Service, Wildlife Services, National Wildlife Research Center, Fort Collins, CO

Susan E. Pettit

United States Department of Agriculture, Animal and Plant Health Inspection Service, Wildlife Services, National Wildlife Research Center, Fort Collins, CO

Jeremy W. Ellis

United States Department of Agriculture, Animal and Plant Health Inspection Service, Wildlife Services,

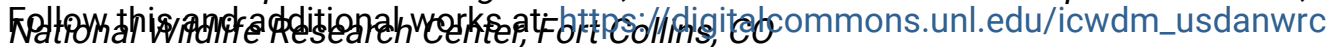

Part of the Life Sciences Commons

See next page for additional authors

Werner, Scott J.; DeLiberto, Shelagh T.; Mangan, Anna M.; Pettit, Susan E.; Ellis, Jeremy W.; and Carlson, James C., "Anthraquinone-based repellent for horned larks, great-tailed grackles, American crows and the protection of California's specialty crops" (2015). USDA National Wildlife Research Center - Staff Publications. 1722.

https://digitalcommons.unl.edu/icwdm_usdanwrc/1722

This Article is brought to you for free and open access by the U.S. Department of Agriculture: Animal and Plant Health Inspection Service at DigitalCommons@University of Nebraska - Lincoln. It has been accepted for inclusion in USDA National Wildlife Research Center - Staff Publications by an authorized administrator of DigitalCommons@University of Nebraska - Lincoln. 


\section{Authors}

Scott J. Werner, Shelagh T. DeLiberto, Anna M. Mangan, Susan E. Pettit, Jeremy W. Ellis, and James C. Carlson 


\title{
Anthraquinone-based repellent for horned larks, great-tailed grackles, American crows and the protection of California's specialty crops
}

\author{
Scott J. Werner*, Shelagh T. DeLiberto, Anna M. Mangan, Susan E. Pettit, Jeremy W. Ellis, \\ James C. Carlson
}

United States Department of Agriculture, Animal and Plant Health Inspection Service, Wildlife Services, National Wildlife Research Center, 4101 LaPorte Avenue, Fort Collins, CO 80521-2154, USA

\section{A R T I C L E I N F O}

\section{Article history:}

Received 22 December 2014

Received in revised form

15 March 2015

Accepted 21 March 2015

Available online 27 March 2015

\section{Keywords:}

Corvus brachyrhynchos

Eremophila alpestris

Human-wildlife conflicts

Quiscalus mexicanus

Vertebrate pest

Wildlife damage management

\begin{abstract}
A B S T R A C T
Specialty crops include fresh and dried fruits, vegetables, tree nuts, and horticultural and nursery crops. California accounts for $28 \%$ of the specialty crop acreage in the United States of America, including $72 \%$ of U.S. lettuce production (Lactuca sativa L.), $27 \%$ of U.S. melon production and $100 \%$ of U.S. almond production (Prunus dulcis L.). We conducted controlled feeding experiments to evaluate an anthraquinonebased repellent for horned larks (Eremophila alpestris L.), great-tailed grackles (Quiscalus mexicanus Gmelin) and American crows (Corvus brachyrhynchos Brehm) associated with the depredation of California's lettuce, melon and almond crops, respectively. We observed $38-100 \%$ feeding repellency among horned larks offered wheat seeds (Triticum spp. L.) treated with 168-3010 ppm anthraquinone during the concentration-response experiment. Great-tailed grackles exposed to rice seeds (Oryza sativa L.) treated with 2060-35,400 ppm anthraquinone exhibited 90-100\% repellency. We observed 80-100\% repellency among American crows offered almonds treated with 2980-31,500 ppm anthraquinone. We predicted a threshold concentration of 5200 ppm anthraquinone for American crows offered treated almonds. Our laboratory efficacy data provide a reliable basis for planning future field applications of anthraquinone-based bird repellents for the protection of specialty crops. Supplemental field efficacy studies are necessary for the registration of avian repellents and the management of agricultural depredation caused by wild birds.
\end{abstract}

Published by Elsevier Ltd.

\section{Introduction}

Within the United States of America, the designation of commodity and specialty crops is intended to highlight the differences between non-perishable crops such as grains (e.g. corn, Zea mays L.; soybeans, Glycine max L.) and the foods people eat directly (http:// www.ucsusa.org/publications/ask/2011/fruits-and-veg.html\#. VDcA03KKBMw). The value of farm-level specialty crop production in 2012 totaled nearly $\$ 60$ billion, representing approximately onefourth of the value of U.S. crop production, yet specialty crops encompass only $3 \%$ of harvested cropland in the U.S. (USDA NASS, 2009; Johnson, 2014). In addition to the relatively high value of specialty crops, the production costs per ha are higher for specialty crops than non-specialty crops (GAO/RCED, 1999).

Specialty crop production within the U.S. is mainly located in

\footnotetext{
* Corresponding author

E-mail address: Scott.J.Werner@aphis.usda.gov (S.J. Werner).
}

California, Florida, Washington, Oregon, North Dakota and Michigan (Johnson, 2014). California accounts for $28 \%$ of the specialty crop acreage in the U.S. (USDA NASS, 2009), including $72 \%$ of U.S. lettuce production (Lactuca sativa L.), 27\% of U.S. melon production (cantaloupe and honeydew [Cucumis spp. Naudin], and watermelon [Citrullus lanatus Matsum. \& Nakai]) and 100\% of U.S. almond production (Prunus dulcis L.; USDA NASS, 2014). Several bird species cause monetary losses to agricultural production in California. Gebhardt et al. (2011) identified Alaudidae (larks), Corvidae (crows, jays), Fringillidae (finches) and Turdidae (thrushes) as some of the primary bird families that cause damage to economically important crops in California.

Several birds can cause damage to California's economicallyimportant lettuce, melon and almond crops (Table 1). Horned larks (Eremophila alpestris L.) uniquely consume lettuce seeds, uproot seedlings, and graze seedling leaves (i.e. cotyledons). Damaged lettuce seedlings are typically stunted or disfigured, and thus disrupt harvest schedules. Great-tailed grackles (Quiscalus 
Table 1

Economically-important specialty crops for California agriculture associated with bird depredation (NASS 2014).

\begin{tabular}{|c|c|c|c|c|}
\hline $\begin{array}{l}\text { Specialty } \\
\text { crop }\end{array}$ & $\begin{array}{l}\text { Hectares } \\
\text { planted } \\
\text { (California) }\end{array}$ & $\begin{array}{l}\text { Production } \\
\text { Value }\end{array}$ & $\begin{array}{l}\text { Yield loss } \\
\text { per damaged } \\
\text { hectare }^{\mathrm{a}}(\%)\end{array}$ & $\begin{array}{l}\text { Depredating } \\
\text { bird species }{ }^{\mathrm{b}, \mathrm{c}, \mathrm{d}}\end{array}$ \\
\hline Lettuce & 81,340 & $\$ 1.7$ billion & 6.1 & Horned Lark \\
\hline Melons & 25,700 & $\$ 334.5$ million & 4.2 & $\begin{array}{l}\text { Great-tailed } \\
\text { Grackle/ } \\
\text { American Crow }\end{array}$ \\
\hline Almonds & 339,940 & $\$ 5.8$ billion & 5.1 & American Crow \\
\hline \multicolumn{5}{|c|}{$\begin{array}{l}\text { a Data from Gebhardt et al., } 2011 . \\
\text { b Hasey and Salmon, 1993; Hamby and Zalom, } 2013 . \\
\text { c Koehler, 1962; Clark, 1976; York et al., } 2000 . \\
\text { d Rappole et al. 1989; LeBoeuf, 2002. }\end{array}$} \\
\hline
\end{tabular}

mexicanus Gmelin) have been observed to damage citrus groves in Texas (Hobbs and Leon, 1987; Johnson et al., 1989; Glahn et al., 1997). Bird damage to young and ripening melons makes the fruit unfit for harvest (LeBoeuf, 2002). Crows can cause damage to agricultural production by consuming crop seeds and seedlings (Heckmanns and Meisenheimer, 1944; Kennedy and Connery, 2008). Crows consume almonds in orchards as they mature and they cause almonds to fall to the ground, thus making them unsuitable for harvest (Gardner, 1926; Emlen, 1937; Hasey and Salmon, 1993). Recent studies also suggest that increasing bird damage in almond orchards is correlated with an increasing infestation of navel orangeworms (Amyelois transitella Walker), an insect that feeds directly on the nut meat of almonds and thus makes them unmarketable (Hamby and Zalom, 2013).

Damage to specialty crops has motivated the use of several bird damage management techniques, including chemical repellents. Although methiocarb effectively reduced horned lark damage to lettuce seedlings in aviary tests (Cummings et al., 1998) and a field enclosure study (York et al., 2000), methiocarb is no longer registered as a bird repellent in the U.S. for use on agricultural crops. Methyl anthranilate, a naturally occurring compound, did not provide effective repellency when applied as a foliar spray (i.e. $\mathrm{CO}_{2}$ backpack sprayer and/or tractor-mounted sprayer) to lettuce and cantaloupe (Umeda and Sullivan, 2001), and ripening rice and sunflower (Werner et al., 2005). Recent laboratory efficacy studies have estimated the threshold concentration of anthraquinone as a chemical repellent for Canada geese (Branta canadensis L.), redwinged blackbirds (Agelaius phoeniceus L.), ring-necked pheasants (Phasianus colchicus L.; Werner et al., 2009), common grackles (Q. quiscula L.; Werner et al., 2011), European starlings (Sturnus vulgaris L.; Tupper et al., 2014) and wild turkeys (Meleagris gallopavo L.; Werner et al., 2014a).

The present study was designed to evaluate the repellency of an anthraquinone-based repellent and develop an anthraquinone concentration-response relationship for horned larks, great-tailed grackles and American crows (Corvus brachyrhychos Brehm) in captivity. These bird species-specific, concentration-response relationships will provide the basis for future field studies to better determine the utility of anthraquinone-based repellents for protecting California's specialty crops from bird damage. The capture, care and use of all birds associated with these experiments were approved by the Animal Care and Use Committee of the United States Department of Agriculture's (USDA) National Wildlife Research Center (NWRC Study Protocols QA-1825, QA-1902 and QA-1939; S.J. Werner- Study Director).

\section{Methods}

The anthraquinone-based repellent used for each of three feeding experiments included 50\% 9,10-anthraquinone (Avipel ${ }^{\mathbb{R}}$ Shield, Arkion Life Sciences, New Castle, DE, USA). Horned larks and American crows were maintained in individual cages, and greattailed grackles were maintained in a group during quarantine and holding by the NWRC Animal Care Unit. All birds were quarantined for a minimum of five days prior to testing. Water was provided ad libitum to each test subject throughout the study (quarantine, holding, acclimation, testing). A nutrient-complete maintenance diet was provided ad libitum to each test subject throughout quarantine and holding. The maintenance diet for horned larks included $45 \%$ millet, $33 \%$ crushed poultry feed, $11 \%$ wheat and $11 \%$ cracked corn. The maintenance diet for great-tailed grackles included equal parts of cracked corn, milo, safflower, small-kibble dog food and rice. The maintenance diet for American crows included dry dog food (i.e. mixed kibble).

For each of three feeding experiments, test subjects acclimated within individual cages for five days subsequent to quarantine and holding. During the acclimation period, one bowl of unadulterated test diet was presented ad libitum within each cage at approximately $0800 \mathrm{~h}$, daily. During the three days subsequent to the acclimation period (i.e. pre-test), one bowl of unadulterated test diet (30 $\mathrm{g}$ for horned larks, $75 \mathrm{~g}$ for great-tailed grackles and American crows) was presented within each cage at approximately 0800 h, daily. Daily consumption of the test diet was measured for each test subject $( \pm 0.1 \mathrm{~g})$ throughout the pre-test (including spillage and desiccation; Werner et al., 2009).

We ranked birds based upon average pre-test consumption and assigned them to one of several test groups such that each group was similarly populated with birds that exhibited high-low daily consumption. We randomly assigned test treatments (i.e. Avipel ${ }^{\circledR}$ Shield-treated test diet) among groups. Test treatments were formulated by applying aqueous suspensions to test diets $(60-100 \mathrm{ml} / \mathrm{kg})$ using a rotating mixer and household spray equipment (Werner et al., 2009). A 100-g sample of each formulated test diet was collected within $24 \mathrm{~h}$ of each feeding experiment and then submitted the NWRC Analytical Chemistry Unit for their quantification of anthraquinone residues among test treatments (i.e. high performance liquid chromatography; Werner et al., 2011, 2014a,b).

The dependent measure of our feeding experiments was calculated as test consumption of repellent-treated test diet relative to average pre-test consumption of untreated test diet (i.e. percent repellency $=$ [one - (group-average test consumption/ group-average pre-test consumption)] ${ }^{*} 100$ ). Logarithmic regression procedures (Proc Reg, SAS v9.2) were used to analyze repellency as a function of anthraquinone concentration. Repellent dose (mg anthraquinone/kg body mass) and threshold repellent concentration (ppm anthraquinone) were estimated for bird species that exhibited significant concentration-response relationships including $\leq \mathbf{8 0} \%$ and $\geq \mathbf{8 0} \%$ repellency (Werner et al., 2009).

\subsection{Horned larks and anthraquinone seed treatment}

The purpose of this experiment was to develop an anthraquinone concentration-response relationship for horned larks in captivity. Rather than a foliar repellent application to emergent lettuce seedlings under field conditions (York et al., 2000; Cummings et al., 2006), wheat seeds were selected as the test diet based upon our previous observations of seasonal food selection and energetic requirements of horned larks under captive and field conditions. Thus, this experiment involved concentrationresponse testing among individually-caged horned larks $(N=54)$ offered whole wheat seeds treated with the Avipel ${ }^{\mathbb{R}}$ Shield repellent.

On the day subsequent to the pre-test (i.e. test), one bowl (30 g 
of repellent-treated wheat) was presented within each cage at approximately $0800 \mathrm{~h}$. Tested anthraquinone concentrations replicated those previously used to develop a concentrationresponse relationship for red-winged blackbirds offered treated rice (Oryza sativa L.) and sunflower seeds (Helianthus spp. L.; Werner et al., 2009). Thus, horned larks in treatment groups 1-6 ( $n=9$ horned larks per group) received one bowl of $0.02 \%, 0.035 \%$, $0.05 \%, 0.1 \%, 0.25 \%$, or $0.5 \%$ anthraquinone during the test, respectively (target concentrations, wt/wt). Consumption of treated wheat was measured for each test subject $( \pm 0.1 \mathrm{~g})$ at approximately $0800 \mathrm{~h}$ on the morning subsequent to the test (including spillage and desiccation).

\subsection{Great-tailed grackles and anthraquinone seed treatment}

The purpose of this experiment was to develop an anthraquinone concentration-response relationship for great-tailed grackles in captivity. Rather than chemically treating melons under field conditions (Glahn et al., 1997), rice seeds were selected as the test diet based upon our previous observations of seasonal food selection and energetic requirements of great-tailed grackles under captive and field conditions. Thus, this experiment involved concentration-response testing among individually-caged greattailed grackles $(N=54)$ offered rice seeds treated with the Avipel ${ }^{\mathbb{B}}$ Shield repellent.

On the day subsequent to the pre-test, one bowl (75 g of repellent-treated rice) was presented within each cage at approximately $0800 \mathrm{~h}$. Based upon the results from the horned lark feeding experiment, treatments for test groups $1-5$ ( $n=10-11$ birds per group) included targeted concentrations of $0.25 \%, 0.5 \%$, $1.0 \%, 2.0 \%$, and $4.0 \%$ anthraquinone, respectively (wt/wt; Werner et al., 2014a). The methods of the previous concentrationresponse test were otherwise replicated.

\subsection{American crows and anthraquinone-treated almonds}

This experiment involved concentration-response testing among individually-caged American crows $(N=45)$ offered Avipel $^{\circledR}$ Shield-treated almonds (raw, shelled). Groups $1-5$ ( $n=9$ American crows per group) received almonds treated with $0 \%$ (untreated control), $0.5 \%, 1.0 \%, 2.0 \%$, or $4.0 \%$ anthraquinone, respectively (target concentrations, wt/wt; Werner et al., 2014a). The methods of the previous concentration-response tests were otherwise replicated with $75 \mathrm{~g}$ of repellent-treated almonds.

\section{Results}

\subsection{Horned larks and anthraquinone seed treatment}

We observed 38-100\% feeding repellency among horned larks offered wheat seeds treated with the Avipel ${ }^{\circledR}$ Shield repellent (Fig. 1). Actual anthraquinone concentrations from our wheat seed treatments ranged from 168 to 3010 ppm anthraquinone (Fig. 1). Lark repellency was not related to actual anthraquinone concentrations (adjusted $r^{2}=0.44 ; P=0.0914$ ). We observed $100 \%$ feeding repellency, however, among horned larks offered wheat seeds treated with $3010 \mathrm{ppm}$ anthraquinone; we previously targeted $\geq 80 \%$ repellency for our concentration-response experiments (Werner et al., 2009). Thus, horned larks were effectively repelled from wheat seeds treated with $>3000$ ppm anthraquinone (Fig. 1).

\subsection{Great-tailed grackles and anthraquinone seed treatment}

Great-tailed grackles exposed to rice seeds treated with the Avipel ${ }^{\circledR}$ Shield repellent exhibited $90-100 \%$ repellency during the

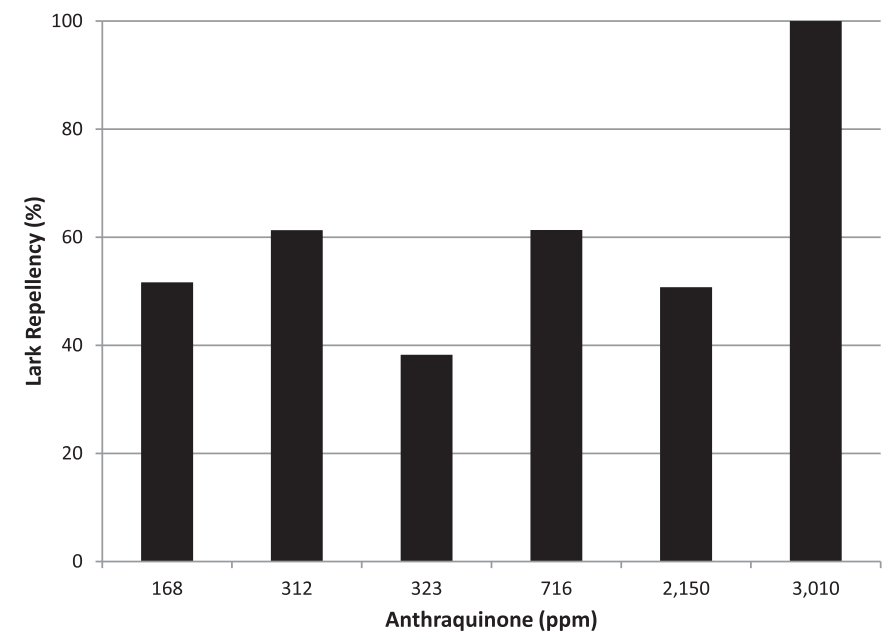

Fig. 1. Mean feeding repellency associated with varying concentrations of Avipel ${ }^{\circledR}$ Shield (a.i. 50\% 9,10-anthraquinone) offered to horned larks (Eremophila alpestris L.). Repellency represents test consumption of repellent-treated wheat seeds relative to average, pre-test consumption of untreated wheat seeds $(n=$ nine larks/ concentration).

concentration-response experiment (Fig. 2). Actual anthraquinone concentrations from our rice seed treatments ranged from 2060 to 35,400 ppm anthraquinone (Fig. 2). Great-tailed grackle repellency (y) was a function of anthraquinone concentration (x): $\mathrm{y}=3.110$ $\ln (\mathrm{x})+67.366$ (adjusted $r^{2}=0.71, P=0.0471$ ).

\subsection{American crows and anthraquinone-treated almonds}

American crows exposed to almonds treated with the Avipel ${ }^{\circledR}$ Shield repellent exhibited $80-100 \%$ repellency during the concentration-response experiment (Fig. 3). Crows in the untreated control group consumed more untreated almonds during the test than those during the pre-test; $-64 \%$ repellency (i.e. attraction) was observed in the control group. Actual anthraquinone concentrations from our Avipel ${ }^{\circledR}$ Shield-treated almonds ranged from 2980 to 31,500 ppm anthraquinone (Fig. 3). Thus, American crows exhibited $80 \%$ repellency for almonds treated with $2980 \mathrm{ppm}$

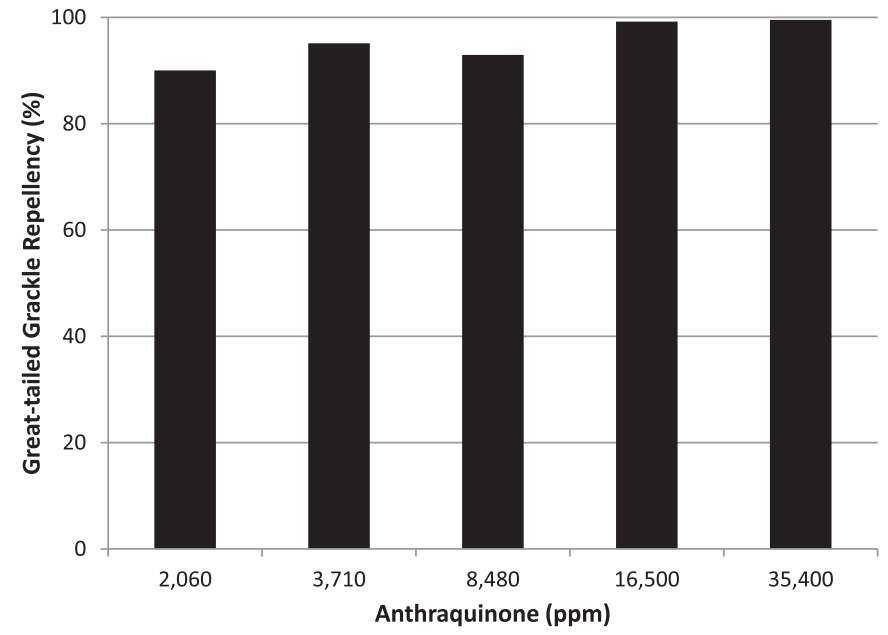

Fig. 2. Mean feeding repellency associated with varying concentrations of Avipel ${ }^{\circledR}$ Shield (a.i. 50\% 9,10-anthraquinone) offered to great-tailed grackles (Quiscalus mexicanus Gmelin). Repellency represents test consumption of repellent-treated rice seeds relative to average, pre-test consumption of untreated rice seeds ( $n=10-11$ grackles/ concentration). 
anthraquinone (Fig. 3), or $4.5 \pm 2.3 \mathrm{mg}$ anthraquinone/kg body mass. Crow repellency (y) was a function of anthraquinone concentration $(\mathrm{x}): \mathrm{y}=17.130 \ln (\mathrm{x})-66.246$ (adjusted $r^{2}=0.98$, $P=0.0006)$. We therefore predicted a threshold concentration of $5200 \mathrm{ppm}$ anthraquinone for American crows offered treated almonds.

\section{Discussion}

This study examined the efficacy of an anthraquinone-based repellent for horned larks, great-tailed grackles and American crows in captivity. Avipel ${ }^{\circledR}$ Shield effectively repelled each of these bird species at some concentration during our captive feeding experiments. Although many candidate repellents exist, Cummings et al. (1998) observed no significant difference in horned lark consumption of untreated, clay-coated lettuce seeds and claycoated lettuce seeds treated with Rejex-it ${ }^{\mathbb{R}}$ AG- 145 (active ingredient methyl anthranilate), Mesurol ${ }^{\circledR}$ (a.i. methiocarb), activated charcoal, or lime. The anthraquinone concentration needed for $\geq 80 \%$ repellency in our study was least for great-tailed grackles and greatest for horned larks. Interestingly, the body mass of wild birds associated with agricultural depredation (e.g. range of body mass $=30-45 \mathrm{~g}$ for horned larks, $100-250 \mathrm{~g}$ for great-tailed grackles, $475-550 \mathrm{~g}$ for American crows) is not directly related to anthraquinone concentrations sufficient for threshold repellency (Werner et al., 2009). Moreover, $\geq 80 \%$ repellency of Avipel ${ }^{\mathbb{B}}$ Shield was observed at lower concentrations for great-tailed grackles ( $\geq 2060 \mathrm{ppm}$ anthraquinone) than common grackles in captivity ( $\geq 9000$ ppm anthraquinone; Werner et al., 2011). We therefore recommend bird species-specific efficacy testing of avian repellents for the protection of agricultural crops. These laboratory efficacy data provide a reliable basis for planning future field applications of chemical repellents for the protection of specialty crops.

Chemical repellents can be part of an integrated pest management (IPM) strategy for the protection of economically-important specialty crops from avian depredation. The greatest avian pest for California's lettuce production are horned larks (Dr. Roger Baldwin, University of California-Davis, pers. commun.). Most lettuce damage occurs before seedlings have $2-3$ true leaves. Lettuce is more tolerant to bird damage after the plant has grown past the three-leaf stage. Thus, preplant seed treatments including chemical

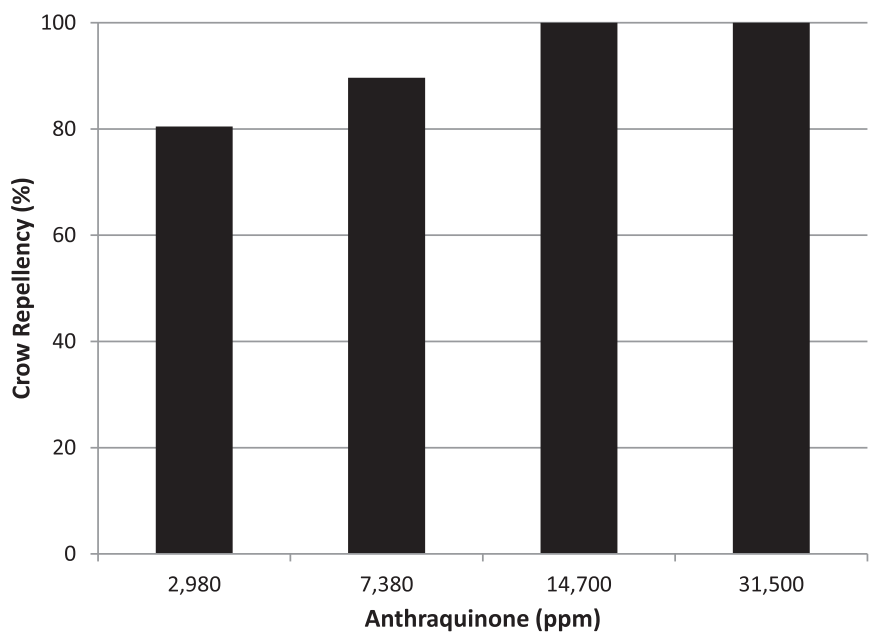

Fig. 3. Mean feeding repellency associated with varying concentrations of Avipel ${ }^{\circledR}$ Shield (a.i. 50\% 9,10-anthraquinone) offered to American crows (Corvus brachyrhynchos Brehm). Repellency represents test consumption of repellent-treated almonds relative to average, pre-test consumption of untreated almonds ( $n=$ nine crows) concentration). repellents and/or foliar applications of chemical repellents to seedlings with 1-2 true leaves (UC IPM Pest Management Guidelines: Lettuce, 2009 http://www.ipm.ucdavis.edu/PMG/r441311311. html), or during the two weeks subsequent to seedling emergence (York et al., 2000), are recommended. In addition to candidate repellents, IPM strategies for the protection of lettuce from horned lark damage include the combination of scare tactics (auditory and visual deterrents) and the use of lettuce transplants (i.e. plug planting within wire mesh, bird netting or other types of covering to deter birds; http://www.ipm.ucdavis.edu/PMG/r441311311. html).

For other avian pests for specialty crops (e.g. great-tailed grackles, American crows), IPM strategies might include several damage management techniques used in combination to effectively minimize crop depredation. These techniques include chemical repellents; mechanical, visual and auditory frightening agents; roost and flock harassment; decoy crops; cultural practices; habitat management and lethal damage management (Linz et al., 2011). The ultimate effectiveness of chemical repellents is dependent upon their efficacy under field conditions, cost relative to expected damages of unmanaged crops, environmental impacts, and food and feed safety (Werner et al., 2009). Optimized repellent formulations and application strategies are needed for protection of newly-planted (e.g. lettuce) and ripening crops (melons, almonds) in context of these economic, environmental, and safety thresholds. For example, ultraviolet cues may enhance repellency of costeffective applications of anthraquinone-based repellents throughout the period of needed repellency (Werner 2009).

Supplemental field efficacy studies are necessary for the registration of avian repellents and the management of agricultural depredation caused by wild birds. Specifically, we recommend field efficacy testing for (1) horned larks exposed to lettuce seeds (i.e. preplant seed treatments, including repellent-treated clay coatings; Cummings et al., 1998) and lettuce seedlings (foliar applications to emergent seedlings) treated with $\geq 3000 \mathrm{ppm}$ anthraquinone, (2) great-tailed grackles exposed to ripening melons treated with $\geq 2000 \mathrm{ppm}$ anthraquinone and (3) American crows exposed to ripening almonds treated with $\geq 3000 \mathrm{ppm}$ anthraquinone. Field efficacy studies for the protection of specialty crops should include independent field replicates with predicted bird damage or bird enclosures within experimental fields (York et al., 2000; Cummings et al., 2006; Werner et al., 2011, 2014b), pre- and at-harvest repellent residues, and bird damage and crop yield measurements. Such field studies are necessary to reconcile efficacy observed under captive and field conditions, and to enable the commercial development of chemical repellents for the protection of agricultural production, including California's specialty crops.

\section{Acknowledgments}

This research was supported in part by California Department of Food and Agriculture's Specialty Crop Block Grant to S.J.W. (Grant Agreement SCB10034). Our feeding experiments were conducted with Avipel ${ }^{\circledR}$ Shield repellent (Arkion ${ }^{\circledR}$ Life Sciences, New Castle, DE, USA). Corporate collaborations do not imply endorsement by the United States Department of Agriculture. We appreciate the National Wildlife Research Center animal care staff that provided daily care throughout our feeding experiments. We also thank D.A. Reid for constructive feedback from his review of our manuscript.

\section{References}

Clark, D.O., 1976. An overview of depredating bird damage control in California. Bird. Semin. Control Semin. 7, 21-27. 
Cummings, J.L., Pochop, P.A., Yoder, C.A., Davis Jr., J.E., 1998. Potential bird repellents to reduce bird damage to lettuce seed and seedlings. Vertebr. Pest Conf. 18, $350-353$.

Cummings, J.L., York, D.L., Primus, T.M., Engeman, R.M., Mauldin, R.E., 2006. Effectiveness of Flight Control ${ }^{\mathrm{TM}}$ to reduce damage to lettuce seedlings from horned larks. Vertebr. Pest Conf. 22, 225-227.

Emlen, J.T., 1937. Bird damage to almonds in California. Condor 39, 192-197.

Gardner, L.L., 1926. Experiments in the economic control of the Western crow (Corvus brachyrhynchos hesperis). Auk 43, 447-461.

Gebhardt, K., Anderson, A.M., Kirkpatrick, K.N., Shwiff, S.A., 2011. A review and synthesis of bird and rodent damage estimates to select California crops. Crop Prot. 30, 1109-1116.

Glahn, J.F., Palacios, J.D., Garrison, M., 1997. Controlling great-tailed grackle damage to citrus in the Lower Rio Grande Valley, Texas. Proc. East. Wildl. Dam. Manage. Conf. 8, 158-172.

Hamby, K.A., Zalom, F.G., 2013. Relationship of almond kernel damage occurrence to Navel Orangeworm (Lepidoptera: Pyralidae) success. J. Econ. Entomol. 106, 1365-1372.

Hasey, J., Salmon, T.P., 1993. Crow damage to almonds increasing; no foolproof solution in sight. Calif. Agric. 47, 21-23.

Heckmanns, F., Meisenheimer, M., 1944. Protection of seeds against birds. United States Patent Office, Patent \#2,339,335.

Hobbs, J., Leon, F.G., 1987. Great-tailed grackle predation on south Texas citrus (identifying a unique problem). Proc. East. Wildl. Dam. Manage. Conf. 3, 143-148.

Johnson, R., 2014. Fruits, Vegetables, and Other Specialty Crops: Selected Farm Bill and Federal Programs. Congressional Research Service, 7-5700 R42771.

Johnson, D.B., Guthery, F.S., Koerth, N.E., 1989. Grackle damage to grapefruit in the Lower Rio Grande Valley. Wildl. Soc. Bull. 17, 46-50.

Kennedy, T.F., Connery, J., 2008. An investigation of seed treatments for the control of crow damage to newly-sown wheat. Ir. J. Agric. Food Res. 47, 79-91.

Koehler, J.W., 1962. Linnets, horned larks, crowned sparrows and woodpeckers. Vertebr. Pest Conf. 1, 174-185.

LeBoeuf, J., 2002. Crop Time Line for Cantaloupes, Honeydews, and Watermelons in California. Report Provided to U.S. EPA Office of Pesticide Programs.

Linz, G.M., Homan, H.J., Werner, S.J., Hagy, H.M., Bleier, W.J., 2011. Assessment of bird-management strategies to protect sunflower. BioSci. 61, 960-970.

Rappole, J.H., Kane, A.H., Flores, R.H., Tipton, A.R., Koerth, N., 1989. Seasonal variation in habitat use by great-tailed grackles in the lower Rio Grande Valley. Proc.
Gt. Plains Dam. Cont. Workshop 10, 138-147.

Tupper, S.K. Werner, S.J., Carlson, J.C., Pettit, S.E., Wise, J.C., Lindell, C.A., Linz, G.M. 2014. European starling feeding activity on repellent treated crops and pellets. Crop Prot. 63, 76-82.

Umeda, K., Sullivan, L., 2001. Evaluation of Methyl Anthranilate for Use as a Bird Repellent in Selected Crops. University of Arizona College of Agriculture 2001 Vegetable Report. http://ag.arizona.edu/pubs/crops/az1252/.

United States Department of Agriculture, National Agriculture Statistics Service(USDA NASS), 2009. 2007 Census of Agriculture. In: Specialty Crops, vol. 2 (November).

United States Department of Agriculture, National Agriculture Statistics Service (USDA NASS), 2014. Quick Stats: Fruit and Tree Nuts; Vegetables (accessed 5.10.14.). http://quickstats.nass.usda.gov/.

United States General Accounting Office, Resources, Community, and Economic Development Division (GAO/RCED), 1999. Crop Insurance: USDA's Progress in Expanding Insurance for Specialty Crops. GAO/RCED-99-67.

Werner, S.J., Homan, H.J., Avery, M.L., Linz, G.M., Tillman, E.A., Slowik, A.A. Byrd, R.W., Primus, T.M., Goodall, M.J., 2005. Evaluation of Bird Shield ${ }^{\mathrm{TM}}$ as a blackbird repellent in ripening rice and sunflower fields. Wildl. Soc. Bull. 33, 251-257.

Werner, S.J., 2009. Ultraviolet Strategy for Avian Repellency. U.S.A Patent Application 13/755, 671.

Werner, S.J., Carlson, J.C., Tupper, S.K., Santer, M.M., Linz, G.M., 2009. Threshold concentrations of an anthraquinone-based repellent for Canada geese, redwinged blackbirds, and ring-necked pheasants. Appl. Anim. Behav. Sci. 121, 190-196.

Werner, S.J., Linz, G.M., Carlson, J.C., Pettit, S.E., Tupper, S.K., Santer, M.M., 2011 Anthraquinone-based bird repellent for sunflower crops. Appl. Anim. Behav. Sci. $129,162-169$

Werner, S.J., Buchholz, R., Tupper, S.K., Pettit, S.E., Ellis, J.W., 2014a. Functional significance of ultraviolet feeding cues in wild turkeys. Physiol. Behav. 123, $162-167$.

Werner, S.J., Tupper, S.K., Pettit, S.E., Ellis, J.W., Carlson, J.C., Goldade, D.A. Hofmann, N.M., Homan, H.J. Linz, G.M., 2014b. Application strategies for an anthraquinone-based repellent to protect oilseed sunflower crops from pest blackbirds. Crop Prot. 59, 63-70.

York, D.L., Cummings, J.L., Engeman, R.M., Davis Jr., J.E., 2000. Evaluation of Flight ControlTM and Mesurol $^{\mathbb{R}}$ as repellents to reduce horned lark (Eremophila alpestris) damage to lettuce seedlings. Crop Prot. 19, 201-203. 